\title{
Prediksi Inflasi Indonesia Memakai Model ARIMA dan Artificial Neural Network
}

\author{
Wahyuddin S \\ Magister Sistem Informasi, Universitas Komputer Indonesia \\ J. Dipati Ukur No. 112-116, Bandung, Jawa Barat, Indonesia \\ Email : wahyudipanegara@live.com
}

\begin{abstract}
Abstrak - Inflasi merupakan indikator makro ekonomi yang sangat penting. Berbagai macam metoda prediksi inflasi Indonesia telah dipublikasikan. Namun pencarian metoda prediksi inflasi yang lebih akurat masih menjadi topik menarik. Pada penulisan ini diusulkan sebuah metoda baru untuk prediksi inflasi memakai model ARIMA dan Artificial Neural Network (ANN). Data inflasi yang digunakan adalah data inflasi bulanan year-on-year dari tahun 2010 sampai dengan tahun 2018 yang diterbitkan oleh Badan Pusat Statistik (BPS). Pertama dibuat 2 model ARIMA yaitu model ARIMA tanpa siklus tahunan dan dengan siklus tahunan. Prosedur standar dan diagostics test telah dilakukan antara lain: summary of statistics, analysis of variance (ANOVA), significance of coefficients test, residuals normality, heterocesdacity, dan stability. Dari hasil perbandingan kinerja memakai Root Mean Squared Error (RMSE) diperoleh bahwa model ARIMA dengan siklus tahunan lebih baik. Model tersebut berupa model ARIMA $(2,1,0)(2,0,0)$ [12]. Kemudian, untuk meningkatkan kinerja prediksi inflasi, ANN telah dibuat berbasis model ARIMA tersebut. Model ANN memakai satu hidden layer dan dua neuron. Hasil pengujian menunjukkan bahwa model ANN menghasilkan RMSE yang lebih kecil daripada model ARIMA $(2,1,0)(2,0,0)[12]$. Hal ini kemungkinan disebabkan oleh kemampuan mengolah hubungan nonlinear antara variabel target dan variabel penjelas.
\end{abstract}

Kata kunci — Prediksi, Arima, Artificial Neural Network, Anova, R programming.

Abstract - Inflation is a macroeconomic indicator that is very important. Various kinds of Indonesian inflation prediction methods have been published. However, the search for more accurate inflation prediction methods is still an interesting topic. This writing is proposed a new method for predicting inflation using the ARIMA and Artificial Neural Network (ANN) models. The inflation data used is monthly inflation data year-on-year from 2010 to 2018 issued by the Central Statistics Agency (BPS). The first two ARIMA models are made, the ARIMA model without annual cycles and with annual cycles. Standard procedures and diagostics tests have been carried out including: summary of statistics, analysis of variance (ANOVA), significance of coefficients tests, residuals of normality, heterocesdacity, and stability. From the results of the performance comparison using the Root Mean Squared Error (RMSE), it was found that the ARIMA model with an annual cycle was better. Those models were an ARIMA model $(2,1,0)(2,0,0)$ [12]. Then, to improve the performance of inflation predictions, ANN has been made based on the ARIMA model. The ANN model used one hidden layer and two neurons. The test resulted show that the ANN model produced RMSE which was smaller than the ARIMA model $(2,1,0)(2,0,0)[12]$. This is probably due to the ability to process nonlinear relationships between target variables and explanatory variables.

Index Terms - Prediction, Artificial Neural Network, Arima, Anova, R programming.

\section{Pendahuluan}

Inflasi merupakan indikator makro ekonomi yang sangat penting di dalam dunia bisnis dan ekonomi. Bagi kaum ekonom dan pengusaha hal ini menjadi perhatian utama karena berkaitan erat dengan nilai mata uang. Dengan mengamati berbagai indikator yang berpengaruh terhadap kenaikan inflasi, dengan melihat data sebelumnya prediksi inflasi dapat dilakukan dengan berbagai macam metode. Berbagai macam metoda prediksi inflasi Indonesia telah dipublikasikan. Namun pencarian metoda prediksi inflasi yang lebih akurat masih menjadi topik menarik. Berbagai macam metode untuk mempelajari data time series di dalam suatu prediksi. Dengan metode prediksi data time series, dapat mempelajari pola data yang telah diurutkan berdasarkan waktu. Setelah itu dibangun sebuah model prediksi berdasarkan pola data tersebut. Untuk mencari model prediksi yang terbaik dapat dilakukan dengan cara melihat tingkat error yang dihasilkan, dimana jika nilai error yang lebih kecil merupakan model yang terbaik [1][2].

Pada penelitian sebelumnya mengatakan bahwa hasil peramalan menggunakan metode ARIMA mampu mengikuti pergerakan data aktual dari laju inflasi artikel jurnal di [3]. Pada penelitian lainnya menyimpulkan bahwa semakin panjang frekuensi peramalan maka hasil peramalan akan semakin kurang akurat dan cenderung konstan terlihat dari nilai upper dan lower yang semakin menjauh dari garis forecast [4]. Pada dasarnya, baik software $\mathrm{R}$ maupun minitab keduanya dapat digunakan untuk peramalan ARIMA. Akan tetapi, diketahui bahwa software $\mathrm{R}$ mempunyai tingkat 
keakuratan lebih baik daripada software minitab dalam hal uji stasioneritas [5].

Algoritma Artificial Neural Network akan menghasilkan hasil yang optimal jika menggunakan data atribut yang lebih banyak [6] Peneliti sebelumnya melakukan prediksi inflasi di Indonesia menggunakan ANN dengan 4 variabel diantaranya tingkat suku bunga, uang beredar, nilai kurs dan harga saham [7].

Pada penelitian ini akan digunakan metode prediksi Model ARIMA (Autoregresif Integrated Moving Average) dan ANN (Artificial Neural Network). ARIMA merupakan model prediksi dengan mempelajari satu variable independen untuk melihat nilai masa lalu di dalam prediksi. Sedangkan ANN merupakan model yang dapat mempelajari banyak variable di dalam suatu prediksi. Sehingga hasil penggabungan ARIMA dan ANN, memberikan hasil yang lebih baik dibandingkan dengan model secara individual. Hal ini terlihat dalam pseudo test pada Januari 2010 sampai Desember 2017 dengan membandingan hasil dari ARIMA, ANN dan ARIMA-ANN dengan data aktual tahun 2018. Data yang digunakan adalah data inflasi year on year dari tahun Januari 2010 sampai Desember 2018 dari Bank Indonesia dan Badan Pusat Statistik.

\section{Metodologi Penelitian}

Pertama dilakukan pengimputan data Inflasi Indonesia dari tahun Januari 2010 sampai Desember 2018, (data time series). Proses penggabungan motede tersebut secara garis besar dapat dilihat pada Gambar 2.1.

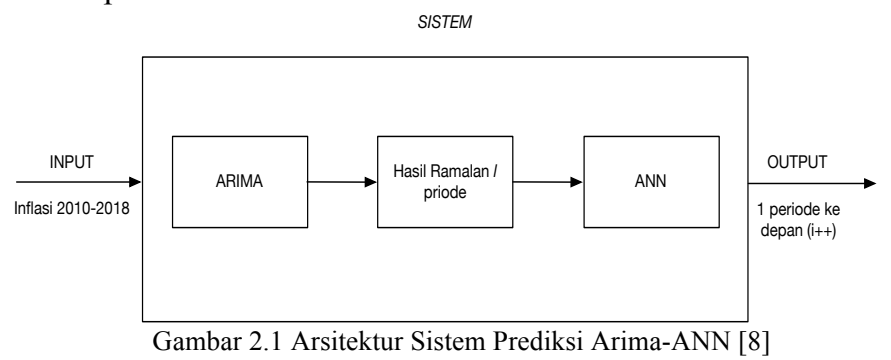

Arsitektur sistem prediksi ARIMA-ANN merupakan penggabungan metode ARIMA dan ANN [8]. Data yang di masukkan dalam ARIMA selama 8 tahun yang artinya 96 bulan (nilai input) data dari tahun Januari 2010 sampai Desember 2018. Dari proses pengimputan data, kemudian dilakukan prediksi menggunakan data tersebut yang dimana merupakan hasil proses ARIMA[9], terlebih dahulu data hasil prediksi menggunakan ARIMA di analisis terlebih dahulu menggunakan ANOVA ( Analysis of Varience ) yang berfungsi untuk menguji perbedaan lebih dari dua kelompok sehingga output dari proses tersebut merupakan model ANN yang terbaik dengan melihat nilai error yang dihasilkan. Nilai error yang lebih kecil merupakan nilai model yang terbaik. Langkah-langkah diagram alir proses ARIMA-ANN dapat dilihat pada Gambar 2.2.

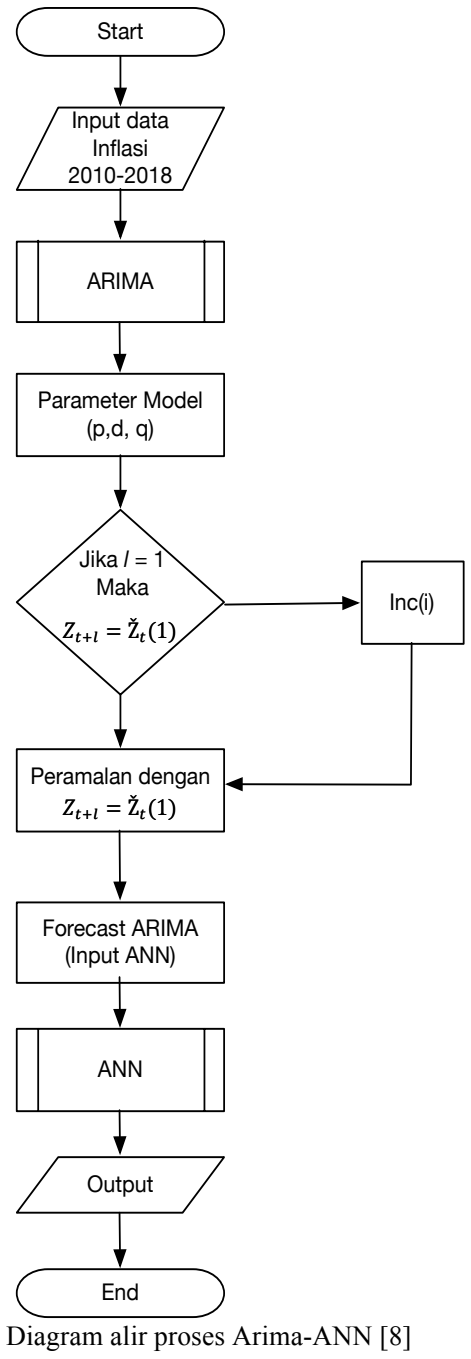

Langkah-langkah Gambar 2.2 sebagai berikut:

a) Input data inflasi dari tahun Januari 2010 sampai Desember 2018 ( 9 Tahun ) atau 108 bulan menggunakan software R Studio.

b) Kemudian di proses menggunakan ARIMA untuk mendapatkan model (p,d,q).

c) Pemilihan model terbaik menggunakan fungsi autoarima pada software $\mathrm{R}$ dimana didapatkan model ARIMA $(2,1,0)(2,0,0)[12]$.

d) Hasil peramalan proses ARIMA di masukkan ke dalam ANN melalui fungsi ANOVA terlebih dahulu.

e) Jika level of significance nilai P-Value $=<0.05$ maka dapat dikatakan memenuhi syarat. 5\% menunjukkan data pada distribusi normal.

f) Output dari hasil penggabungan ARIMA-ANN. 


\section{HASIL DAN PEMBAHASAN}

Data yang diperoleh dari penelitian ini sebanyak 96 record dari data inflasi Januari 2010 sampai Desember 2018, sebagian data digunakan untuk data training dan data testing.

\section{A. Data yang digunakan}

Data yang digunakan untuk pengimputan pada penelitian ini terdiri dari : 1. Suku bunga 2. Tingkat pengangguran 3 . Produk Domestik Regional Bruto Sulawesi Selatan 4. Produk Domestik Bruto Indonesia 5. Upah Minimum Regional Sulawesi Selatan 6. Kurs Jual 7. Kurs Beli, sedangkan data untuk output adalah data Inflasi di Indonesia dari tahun 20102018. Perangkat lunak yang digunakan untuk melakukan peramalan adalah Software RStudio Version 1.1.463.

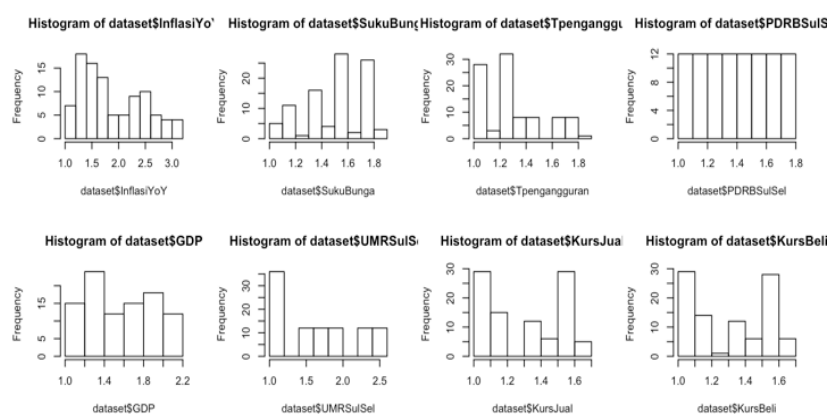

Gambar 3.1 Plot hist dataset

Decomposition of additive time series

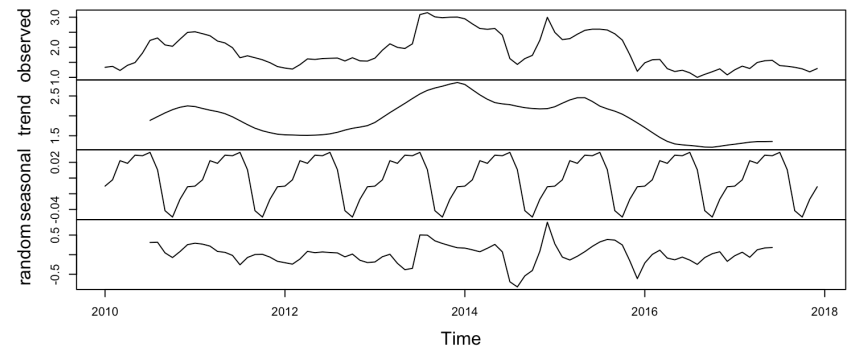

Gambar 3.2 Plot decompose Inflasi year on year

\section{B. Arima Model}

Hasil Pemodelan Arima di tunjukkan pada Gambar 3.3 dan 3.4. Gambar 3.3 menunjukkan ACF dan PACF dari data Inflasi Januari 2010 sampai Desember 2018 2017. Gambar 3.4(a) menunjukkan Inflasi Aktual (Januari 2010 s.d. Desember 2017) dan Inflasi Estimasi (Januari 2010 s.d Desember 2017).Gambar 3.4(b) menunjukkan Inflasi Aktual (Januari 2018 s.d. Desember 2018) dan Inflasi Pseudo Prediksi (Januari 2018 s.d. Desember 2018) menggunakan ARIMA $(2,1,0)(2,0,0)[12],[10][11]$.
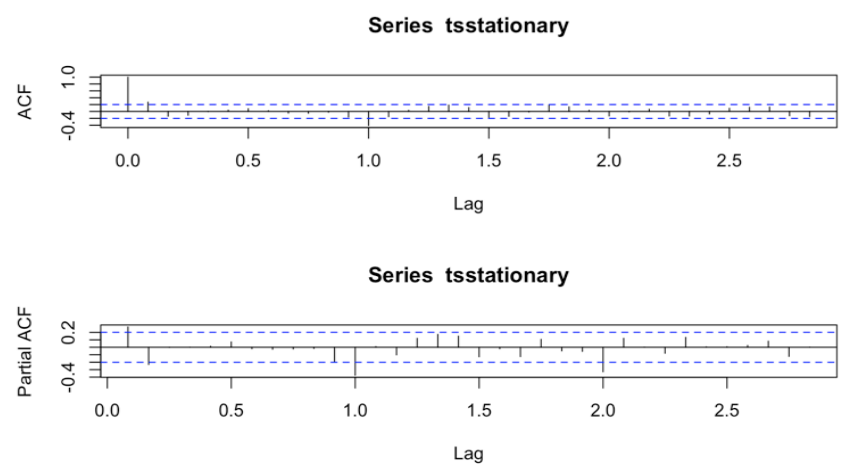

Gambar 3.3 Plot ACF dan PACF

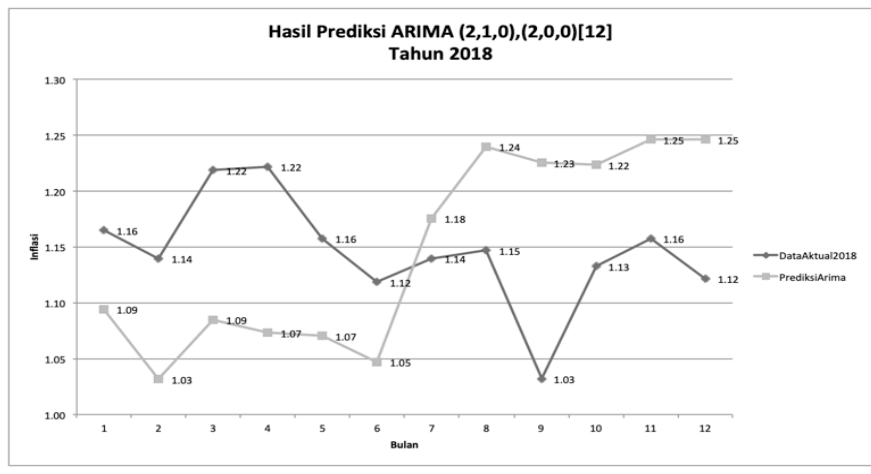

Gambar 3.4 Plot Hasil Prediksi ARIMA 2018

TABEL I

PERBANDINGAN NILAI ERROR ARIMA

\begin{tabular}{ccccccc}
\hline $\begin{array}{c}\text { Peri } \\
\text { od }\end{array}$ & $\begin{array}{c}\text { Aktual } \\
\mathbf{2 0 1 8}\end{array}$ & $\begin{array}{c}\boldsymbol{A R I} \\
\boldsymbol{M A}\end{array}$ & Error & $\begin{array}{c}\text { Ablolute } \\
\text { Value of } \\
\text { Error }\end{array}$ & $\begin{array}{c}\text { Square } \\
\text { of } \\
\text { Error }\end{array}$ & $\begin{array}{c}\text { AbsoluteValu } \\
\text { es of Error } \\
\text { Divided by } \\
\text { Actual Values }\end{array}$ \\
\hline $\boldsymbol{t}$ & $\boldsymbol{A t}$ & $\boldsymbol{F t}$ & $\boldsymbol{A t - F t}$ & $|\boldsymbol{A t}-\boldsymbol{F t}|$ & $\begin{array}{c}(\boldsymbol{A t}-\boldsymbol{F t} \\
\boldsymbol{N}^{\wedge} \mathbf{2}\end{array}$ & $\begin{array}{c}\mid \boldsymbol{A t}-\boldsymbol{F t}) / \\
\boldsymbol{A t} \mid\end{array}$ \\
\hline 1 & 1,16 & 1,09 & 0,07 & 0,07 & 0,00 & 0,06 \\
2 & 1,14 & 1,03 & 0,11 & 0,11 & 0,01 & 0,10 \\
3 & 1,22 & 1,09 & 0,13 & 0,13 & 0,02 & 0,11 \\
4 & 1,22 & 1,07 & 0,15 & 0,15 & 0,02 & 0,12 \\
5 & 1,16 & 1,07 & 0,09 & 0,09 & 0,01 & 0,08 \\
6 & 1,12 & 1,05 & 0,07 & 0,07 & 0,01 & 0,06 \\
7 & 1,14 & 1,18 & $-0,04$ & 0,04 & 0,00 & 0,03 \\
8 & 1,15 & 1,24 & $-0,09$ & 0,09 & 0,01 & 0,08 \\
9 & 1,03 & 1,23 & $-0,19$ & 0,19 & 0,04 & 0,19 \\
10 & 1,13 & 1,22 & $-0,09$ & 0,09 & 0,01 & 0,08 \\
11 & 1,16 & 1,25 & $-0,09$ & 0,09 & 0,01 & 0,08 \\
12 & 1,12 & 1,25 & $-0,12$ & 0,12 & 0,02 & 0,11 \\
\hline & Total & & $-\mathbf{0 , 0 1}$ & $\mathbf{1 , 2 5}$ & $\mathbf{0 , 1 5}$ & $\mathbf{1 , 0 9}$ \\
\hline
\end{tabular}

Hasil prediksi Arima dengan menggunakan model $(2,1,0)$, $(2,0,0)[12]$ menunjukkan nilai MAPE sebesar 9,12\%, MAD 0,10, MSE 0,01, RMSE 0,11. 


\section{ANN Model}

Hasil Pemodelan ANN di tunjukkan pada Gambar 3.5 dan 3.6. Gambar 3.5 menunjukkan Plot Data ANN Dengan Hidden Layer 1, Neuron 3 dari data Inflasi ( Januari 2010 sampai Desember 2018 2017). Gambar 3.6(a) menunjukkan Inflasi Aktual (Januari 2010 s.d. Desember 2017) dan Inflasi Estimasi (Januari 2010 s.d. Desember Demesber 2017) Gambar 3.6(b) menunjukkan Inflasi Aktual (Januari 2018 s.d. Desember 2018) dan Inflasi Pseudo Prediksi (Januari 2018 s.d. Desember 2018) menggunakan model 1 hidden layer 3 neuron [12][13].

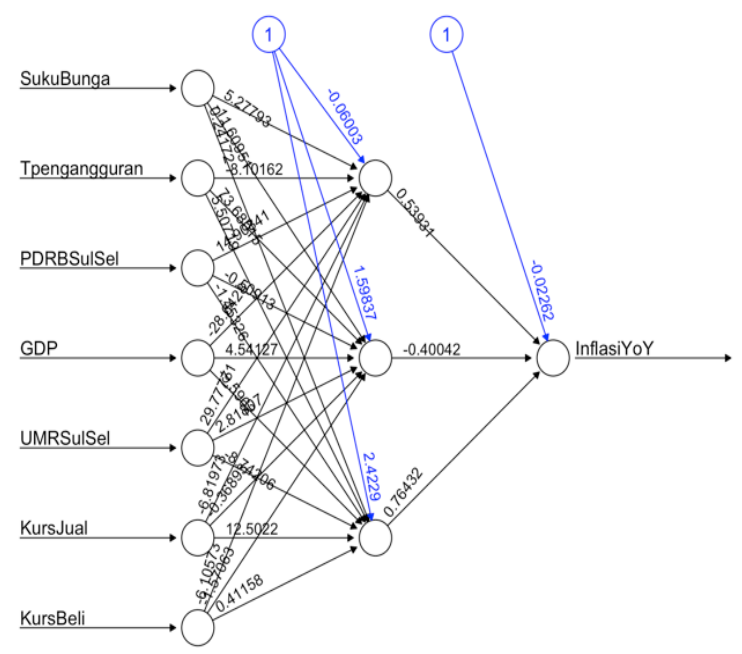

Error: 0.409651 Steps: 1368

Gambar 3.5 Plot Neural Model 1 Hidden Layer 3 Neuron

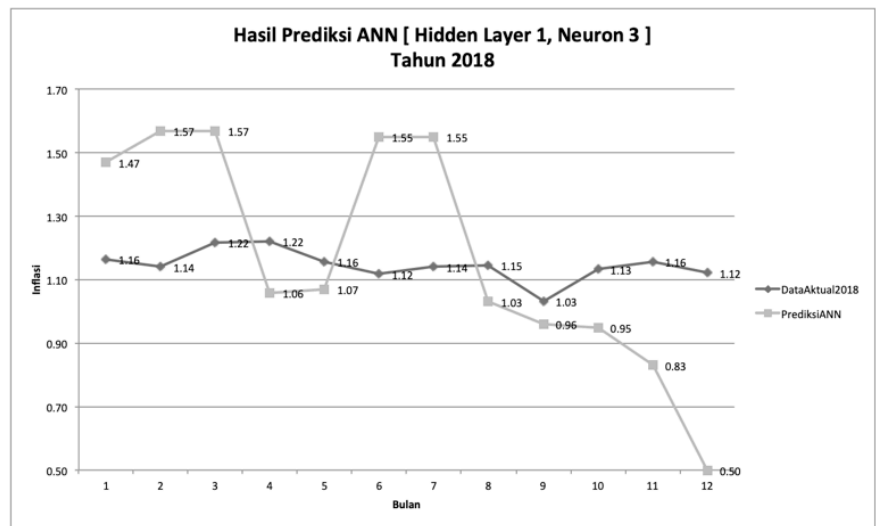

Gambar 3.6 Plot Hasil prediksi ANN Tahun 2018

TABEL I

PERBANDINGAN MODEL ANN

\begin{tabular}{ccc}
\hline No & Model & MSE \\
\hline 1 & 1 Hidden layer 1 Neuron & 2,81 \\
2 & 1 Hidden layer 2 Neuron & 2,56 \\
3 & 1 Hidden layer 3 Neuron & 1,88 \\
4 & 2 Hidden layer 1 Neuron & 2,70 \\
5 & 3 Hidden layer 2 Neuron & 3,16 \\
6 & 3 Hidden layer 1 Neuron & 2,19 \\
7 & 4 Hidden layer 1 Neuron & 1,96 \\
8 & 5 Hidden layer 3 Neuron & 1,89 \\
\hline
\end{tabular}

Perbandingan model ANN pada Tabel I menunjukkan bahwa model ANN dengan 1 Hidden layer dan 3 Neuron merupakan model yang terbaik, hal ini di buktikan dengan nilai MSE yang lebih rendah dengan nilai MSE sebesar 1,88.

TABEL II

PERBANDINGAN NILAI ERROR ANN

\begin{tabular}{ccccccc}
\hline $\begin{array}{c}\text { Peri } \\
\text { od }\end{array}$ & $\begin{array}{c}\text { Aktual } \\
\mathbf{2 0 1 8}\end{array}$ & $\boldsymbol{A N N}$ & Error & $\begin{array}{c}\text { Ablolute } \\
\text { Value of } \\
\text { Error }\end{array}$ & $\begin{array}{c}\text { Square } \\
\text { of } \\
\text { Error }\end{array}$ & $\begin{array}{c}\text { AbsoluteValu } \\
\text { es of Error } \\
\text { Divided by } \\
\text { Actual Values }\end{array}$ \\
\hline $\boldsymbol{t}$ & $\boldsymbol{A t}$ & $\boldsymbol{F t}$ & $\boldsymbol{A t - F t}$ & $|\boldsymbol{A t}-\boldsymbol{F t}|$ & $\begin{array}{c}(\boldsymbol{A t}-\boldsymbol{F t} \\
\boldsymbol{)}^{\wedge} \mathbf{2}\end{array}$ & $\begin{array}{c}\mid \boldsymbol{A t}-\boldsymbol{F t}) / \\
\boldsymbol{A t} \mid\end{array}$ \\
\hline 1 & 1,16 & 1,47 & $-0,31$ & 0,31 & 0,09 & 0,26 \\
2 & 1,14 & 1,57 & $-0,43$ & 0,43 & 0,19 & 0,38 \\
3 & 1,22 & 1,57 & $-0,35$ & 0,35 & 0,12 & 0,29 \\
4 & 1,22 & 1,06 & 0,16 & 0,16 & 0,03 & 0,13 \\
5 & 1,16 & 1,07 & 0,09 & 0,09 & 0,01 & 0,08 \\
6 & 1,12 & 1,55 & $-0,43$ & 0,43 & 0,19 & 0,39 \\
7 & 1,14 & 1,55 & 0,41 & 0,41 & 0,17 & 0,36 \\
8 & 1,15 & 1,03 & 0,12 & 0,12 & 0,01 & 0,10 \\
9 & 1,03 & 0,96 & 0,07 & 0,07 & 0,01 & 0,07 \\
10 & 1,13 & 0,95 & 0,18 & 0,18 & 0,03 & 0,16 \\
11 & 1,16 & 0,83 & 0,33 & 0,33 & 0,11 & 0,28 \\
12 & 1,12 & 0,50 & 0,62 & 0,62 & 0,39 & 0,55 \\
\hline & Total & & $\mathbf{- 0 , 3 6}$ & $\mathbf{3 , 5 0}$ & $\mathbf{1 , 3 4}$ & $\mathbf{3 , 0 5}$ \\
\hline
\end{tabular}

Perbandingan nilai error pada Tabel II dengan menggunakan model ANN, 1 hidden layer dan 3 Neuron menunjukkan nilai $\mathrm{MAD}=0,29, \mathrm{MSE}=0,11, \mathrm{RMSE}=0,33$, MAPE $=25,44$.

\section{Hasil Prediksi}

Hasil Pemodelan Penggabungan Model ANN-ARIMA di tunjukkan pada Gambar 3.7 dan 3.8. Gambar 3.7 menunjukkan Plot Data ANN Dengan Inputan 2 Buah Hidden Layer 1, Neuron 2/1 dari data Inflasi ( Januari 2010 sampai Desember 2018 2017). Gambar 3.8(a) menunjukkan Inflasi Aktual (Januari 2010 s.d. Desember 2017) dan Inflasi Estimasi (Januari 2010 s.d. Desember Desember 2017) Gambar 3.8(b) menunjukkan Inflasi Aktual (Januari 2018 s.d. Desember 2018) dan Inflasi Pseudo Prediksi (Januari 2018 s.d. Desember 2018) menggunakan model 1 hidden layer 2 neuron [14] [15].

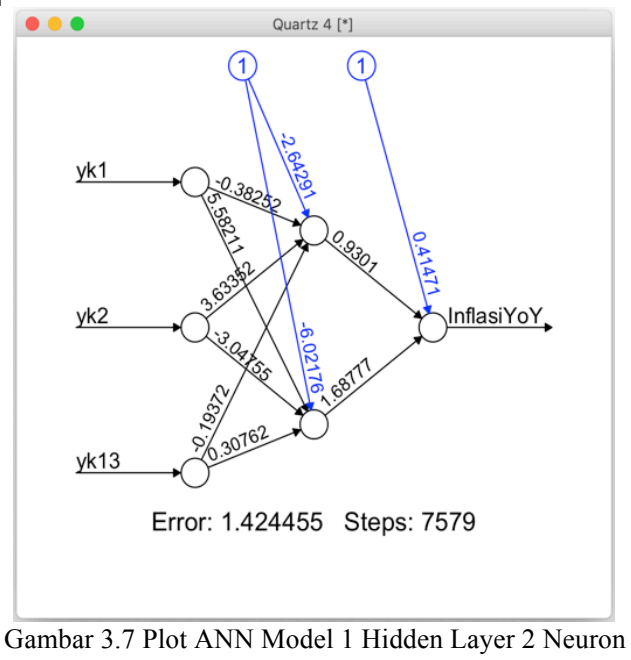




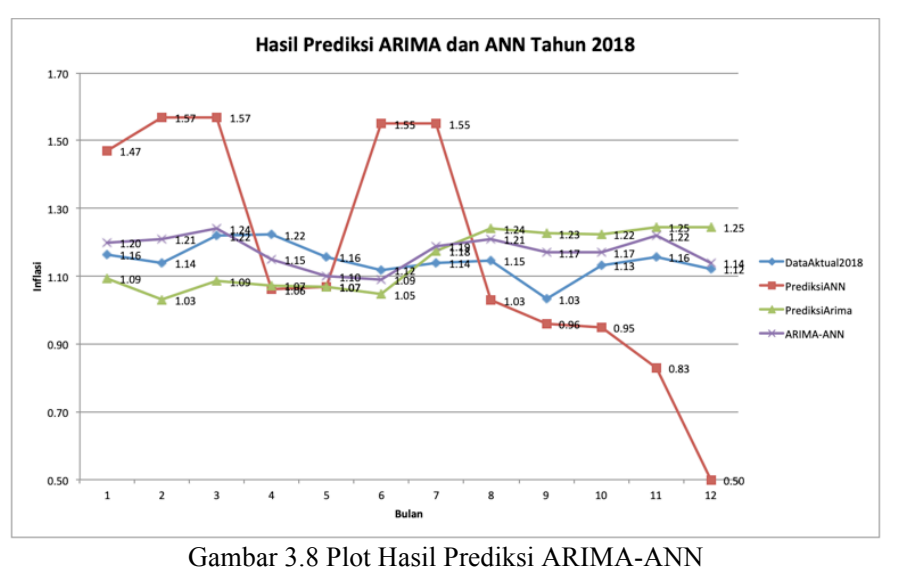

TABEL III

PERBANDINGAN NILAI ERROR ARIMA-ANN

\begin{tabular}{|c|c|c|c|c|c|c|}
\hline $\begin{array}{c}\text { Peri } \\
\text { od }\end{array}$ & $\begin{array}{l}\text { Aktual } \\
2018\end{array}$ & $\begin{array}{l}A R I \\
M A- \\
A N N\end{array}$ & Error & $\begin{array}{l}\text { Ablolute } \\
\text { Value of } \\
\text { Error }\end{array}$ & $\begin{array}{c}\text { Square } \\
\text { of } \\
\text { Error }\end{array}$ & $\begin{array}{c}\text { AbsoluteValu } \\
\text { es of Error } \\
\text { Divided by } \\
\text { Actual Values }\end{array}$ \\
\hline$t$ & $A t$ & $F t$ & $\overline{A t-F t}$ & $|A t-F t|$ & $\begin{array}{c}(A t-F t \\
)^{\wedge} 2\end{array}$ & $\begin{array}{c}\mid(A t-F t) / \\
A t \mid\end{array}$ \\
\hline 1 & 1,16 & 1,20 & $-0,04$ & 0,04 & 0,00 & 0,03 \\
\hline 2 & 1,14 & 1,21 & $-0,07$ & 0,07 & 0,00 & 0,06 \\
\hline 3 & 1,22 & 1,24 & $-0,02$ & 0,02 & 0,00 & 0,02 \\
\hline 4 & 1,22 & 1,15 & 0,07 & 0,07 & 0,01 & 0,06 \\
\hline 5 & 1,16 & 1,10 & 0,06 & 0,06 & 0,00 & 0,05 \\
\hline 6 & 1,12 & 1,09 & $-0,05$ & 0,03 & 0,00 & 0,03 \\
\hline 7 & 1,14 & 1,19 & $-0,06$ & $-0,05$ & 0,00 & 0,04 \\
\hline 8 & 1,15 & 1,21 & $-0,14$ & $-0,06$ & 0,00 & 0,05 \\
\hline 9 & 1,03 & 1,17 & $-0,04$ & $-0,14$ & 0,02 & 0,13 \\
\hline 10 & 1,13 & 1,17 & $-0,06$ & $-0,04$ & 0,00 & 0,03 \\
\hline 11 & 1,16 & 1,22 & $-0,02$ & $-0,06$ & 0,00 & 0,05 \\
\hline \multirow[t]{2}{*}{12} & 1,12 & 1,14 & $-0,02$ & $-0,02$ & 0,00 & 0,02 \\
\hline & Total & & $-0,34$ & 0,65 & 0,05 & 0,58 \\
\hline
\end{tabular}

Perbandingan nilai error dari hasil penggabungan ARIMAANN pada Tabel III dengan menggunakan model ANN, 1 hidden layer dan 2 Neuron menunjukkan nilai $\mathrm{MAD}=0,05$, $\mathrm{MSE}=0,00, \mathrm{RMSE}=0,06, \mathrm{MAPE}=4,82$. Nilai error dari penggabungan ARIMA-ANN menunjukkan nilai error paling rendah di bandingkan dengan ARIMA dan ANN.

\section{E. Software R}

Software R Studio merupakan software open source yang dapat di download secara gratis. Beberapa software yang sering digunakan antara lain, SPSS, Eviews, SAS, Minitab. R Studio dalam versi terakhirnya yaitu v1.1.463 April 2019 baik untuk windows maupun linux. Di dalam penggunaan R Studio berbagai metode yang ingin di terapkan untuk menganalisis data semua menggunakan package yang berbeda-beda sesuai fungsi dan tujuan, package dapat diunduh secara gratis dan diterapkan pada R Studio [16].

\section{KESIMPULAN}

Hasil prediksi inflasi tahun 2018 dengan menggunakan data aktual (Januari 2010 sd Desember 2017) menunjukkan MAPE ARIMA-ANN 4,82\%, ARIMA 9,12\%, ANN 25,44 \%. Model kombinasi ARIMA-ANN adalah model terbaik untuk prediksi nilai inflasi tahun 2018 dengan jumlah hidden layer 1 , jumlah neuron 2 dan memiliki nilai error terkecil sebesar MAPE 4,82\%. Pada proses training, diketahui bahwa banyaknya neuron pada hidden layer sangat mempengaruhi hasil prediksi, baik MSE maupun waktu komputasi.

\section{UCAPAN TERIMA KASIH}

Penelitian ini dilakukan sebagai bagian dari studi Magister Sistem Informasi, Universitas komputer Indonesia (UNIKOM), Bandung - Propinsi Jawa Barat, Indonesia.

\section{REFERENSI}

[1] R. Rismala, "Prediksi Time Series Tingkat Inflasi Indonesia Menggunakan Evolution Strategies," vol. 1, no. 2, p. 5, 2015.

[2] D. Singh, N. Choudhary, and J. Samota, "Analysis of Data Mining Classification with Decision treeTechnique," p. 7, 2013.

[3] Hartati, "Penggunaan Metode Arima Dalam Meramal Pergerakan Inflasi," J. Mat. Sains Dan Teknol., vol. 18, no. $1,2017$.

[4] M. Nawawi, "Peramalan Inflasi Kota Bandung Menggunakan Metode Arima," UNIKOM, 2017.

[5] S. R. P. Astutik and P. Hendikawati, "Peramalan Inflasi di Demak Menggunakan Metode ARIMA Berbantuan Software R dan MINITAB,” p. 10, 2018.

[6] R. H. Kusumodestoni and S. Suyatno, "Prediksi Forex Menggunakan Model Neural Network," Simetris J. Tek. Mesin Elektro Dan Ilmu Komput., vol. 6, no. 2, p. 205, Nov. 2015.

[7] D. Wahyuningsih, I. Zuhroh, and - Zainuri, "Prediksi Inflasi Indonesia Dengan Model Artificial Neural Network," J. Indones. Appl. Econ., vol. 2, no. 2, pp. 22008, Sep. 2008.

[8] D. T. Wiyanti and R. Pulungan, "RBF and ARIMA Combined for Time Series Forecasting," p. 7, 2013.

[9] F. Zheng and S. Zhong, "Time Series Forecasting Using a Hybrid RBF Neural Network and AR Model Based On Binomial Smoothing," vol. 5, no. 3, p. 5, 2011.

[10] Ferry Kondo Lembang, "Prediksi Laju Inflasi di Kota Ambon Menggunakan Metode ARIMA Box Jenkins," vol. 16, no. 2, pp. 95-102, 2016.

[11] F. S. P. Nim, "Penggunaan Metode ARIMA (Autoregressive Integrated Moving Average) untuk Perakiraan Beban Konsumsi Listrik Jangka Pendek,” p. 118.

[12] F. Ciabuschi and B. Venkateswaran, Neural networks with $R$ : smart models using $C N N$, RNN, deep learning, and artificial intelligence principles. 2017.

[13] J. S. D. Raharjo, "Model Artificial Neural Network Berbasis Particle Swarm Optimization Untuk Prediksi Laju Inflasi," p. 12, 2013.

[14] A. Amrin, "Analisa Komparasi Neural Network Backpropagation Dan Multiple Linear Regression Untuk Peramalan Tingkat Inflasi."

[15] J. Binner, R. Bissoondeeal, T. Elger, A. Gazely, and A. Mullineux, "A comparison of linear forecasting models 
and neural networks: an application to Euro inflation and Euro Divisia," Appl. Econ., vol. 37, no. 6, pp. 665-680, Apr. 2005.

[16] Suhartono, Analisis Data Statistik Dengan R. ITS, Surabaya: Lab. Statistik Komputasi, 2008. 